\title{
PERLINDUNGAN PASIEN (Meneropong Perjanjian Pelayanan Medik menurut Undang-undang Nomor 8 Tahun 1999 tentang Perlindungan Konsumen)
}

\author{
Elvie Wahyuni \\ (Dosen Tetap pada Fakultas Hukum Universitas Madura)
}

\begin{abstract}
Abstrak:
Dalam hubungan antara pasien dan dokter, terdapat hubungan yang bersifat perdata dan pidana yang biasa diawali oleh perjanjian atau kontrak untuk mendapat palayanan medik. Dalam hubungan tersebut masing-masing pihak mempunyai hak dan kewajiban. Namun, hingga saat ini belum adanya undang-undang yang memberikan perlindungan atas hak-hak pasien, sehingga masih sering terjadi malpraktik di Indonesia. Karenanya, tulisan ini mengkaji sejauhmana Undang-undang No. 9 tahun 1999 tentang Perlindungan Konsumen memberikan perlindungan terhadap hak-hak pasien yang juga merupakan konsumen dalam perjanjian medik yang diberikan oleh dokter. Menurut UU tersebut, pelayanan medik bisa dikategorikan sebagai pelayanan jasa, beberapa pasal dalam UU tersebut dapat dijadikan acuan, khususnya yang mengatur masalah hak dan kewajiban para pihak, yakni pasien, yang kedudukannya seperti konsumen jasa, dan dokter, yang kedudukannya seperti produsen dalam hal pelayanan jasa
\end{abstract}

Kata Kunci:

pelayanan medik, pasien, dan dokter.

\section{Pendahuluan}

Pembangunan kesehatan ${ }^{1}$ diselenggarakan berasaskan perikemanusiaan yang berdasarkan Ketuhanan Yang Maha Esa,

1 Kesehatan yang dimaksud di sini adalah yang sesuai dengan Undang-undang Nomor 23 tahun 1992, yakni keadaan sejahtera dari badan, jiwa, dan sosial yang memungkinkan setiap orang hidup produktif secara sosial dan ekonomis. Lihat Undang-undang Republik Indonesia Undang-undang Nomor 23 Tahun 1992 tentang Kesehatan (Jakarta: Setneg RI, 1999), hlm. 3. 
manfaat, usaha bersama dan kekeluargaan, adil dan merata, perikehidupan dalam keseimbangan, serta kepercayaan akan kemampuan dan kekuatan sendiri. Selanjutnya untuk mewujudkan derajat kesehatan yang optimal bagi masyarakat, maka upaya kesehatan dilakukan dengan cara pendekatan pemeliharaan dan peningkatan kesehatan, pencegahan penyakit, penyembuhan penyakit, dan pemulihan kesehatan. Kesemuanya itu dilaksanakan secara menyeluruh, terpadu, dan berkesinambungan, dengan sasaran orang perorangan, keluarga, dan kelompok masyarakat secara keselurahan.

Pelayanan medik (health care servies) merupakan salah satu upaya yang dapat dilakukan untuk meningkatkan derajat kesehatan baik perseorangan, maupun kelompok atau masyarakat secara keseluruhan. Pelayanan kesehatan yang dimaksud di sini meliputi setiap upaya baik yang diselenggarakan sendiri atau bersama-sama dalam organisasi untuk meningkatkan dan memelihara kesehatan, mencegah penyakit, mengobati penyakit dan memulihkan kesehatan yang ditujukan terhadap perseorangan, kelompok atau masyarakat. tidak ditemukan rumusan pengertian mengenai pelayanan kesehatan. Singkatnya, menurut Undang-undang Kesehatan pasal 1 ayat 2, upaya kesehatan mencakup setiap kegiatan untuk memelihara dan meningkatkan kesehatan yang dilakukan oleh pemerintah atau masyarakat. $^{2}$

Cakupan masyarakat, dalam pengertian di atas, meliputi perseorangan, keluarga, kelompok masyarakat, dan masyarakat secara keseluruhan. Berdasarkan pengertian tersebut, dapat dipahami bahwa pelayanan kesehatan tersebut banyak macamnya. Secara umum pelayanan kesehatan dibedakan menjadi 2 (dua) macam, yaitu pelayanan kedokteran (medical servis) ${ }^{3}$ dan pelayanan kesehatan masyarakat (public health servies). Kedua pelayanan kesehatan tersebut

2 Undang-undang Republik Indonesia Undang-undang Nomor 23 Tahun 1992 Tentang Kesehatan, hlm. 5.

3 Istilah lain dari pelayanan kedokteran adalah pelayanan medik. Oleh karena itu, pelayanan medis mencakup semua upaya dan kegiatan berupa pencegahan (preventif), pengobatan (kuratif), peningkatan (promotif), dan pemulihan (rehabiliatif) kesehatan yang dilaksanakan atas dasar hubungan indivual antara para ahli di bidang kedokteran dengan individu yang membutuhkannya. 
mempunyai ciri-ciri tersendiri. Secara umum pelayanan kesehatan dapat diselenggarakan sendiri dengan tujuan utamanya adalah untuk mengobati (kuratif) penyakit dan memulihkan (rehabiliatif) kesehatan serta sasaran utamanya adalah perseorangan, sedangkan pelayanan kesehatan masyarakat umumnya diselenggarakan secara bersamasama dalam sebuah organisasi bahkan harus mengikutsertakan potensi masyarakat dan mencegah penyakit serta sasaran utamanya adalah masyarakat secara keseluruhan. ${ }^{4}$

Dalam pelayanan kesehatan tersebut terjadi perjanjian antara pasien dengan dokter/tenaga kesehatan dan rumah sakit. Perjanjian ini berlaku secara sah sebagai undang-undang mengikat bagi para pihak yang terlibat dalam pembuatannya ${ }^{5}$. Perjanjian itu harus dilaksanakan berdasarkan i'tikad baik dari pasien dan dokter/tenaga kesehatan serta rumah sakit. Maka para pihak paham akan posisinya, sehingga kepastian dan rasa perlindungan hukum bagi yang terlibat dalam pelayanan kesehatan dapat terwujud secara baik dan optimal. ${ }^{6}$ Dalam perjanjian ini, pelayanan kesehatan dapat diberikan melalui bentuk pengobatan dan perawatan. Petugas kesehatan, medis dan nonmedis, bertanggungjawab untuk memberi pelayanan yang optimal. Tenaga medis, dalam hal ini dokter, memiliki tanggungjawab terhadap pengobatan yang sedang dilakukan. Tindakan pengobatan dan penentuan kebutuhan dalam proses pengobatan merupakan wewenang dokter.

Namun dalam praktiknya, dalam membuat suatu perjanjian, pasien berada posisi yang sangat tidak menguntungkan, sedangkan

\footnotetext{
${ }^{4}$ Leene, H.J.J Lamintang, P.A.F., Pelayanan Kesehatan dan Hukum (Jakarta: Bina Cipta, 1991), hlm 8

${ }^{5}$ Asas kebebasan berkontrak sebagaimna disebutkan dalam 1338 KUHPerdata, syarat sahnya perjanjian tersebut dapat diterapkan pasal 1320 KUHPerdata, sedangkan untuk pelaksanaan perjanjian itu sendiri harus dilaksanakan dengan i'tikad baik sesuai dengan ketentuan pasal 1338 dan 1339 KUHPerdata. Dengan adanya ketentuan di atas, maka proses terhadap kepastian perlindungan hukum bagi pasien dan rumah sakit terjadi dengan lahirnya kata sepakat yang disertai dengan kecakapan untuk bertindak dalam perjanjian di antara pasien dengan dokter/tenaga kesehatan dan rumah sakit.

6 Redaksi, Perlindungan hukum terhadap Pasien sebagai Pengguna Jasa Pelayanan Kesehatan: http://www.skripsihukum.com/tesis/98543.html (diakses tanggal 2 Nopember 2007).
} 
posisi dokter sangatlah superior. Pasien yang mau berobat atau yang meminta pelayanan medik dihadapkan pada posisi sulit. Minimnya perlindungan pasien sangat menjadi ironi kepada nasib, apakah hakhak pasien mendapatkan perlindungan. Lebih dari itu, apabila terjadi sengketa, misalnya, pasien mengalami kerugian akibat pelayanan yang salah (malapraktik), maka yang terjadi cenderung kasusnya akan di-"peti-es"-kan". Perlindungan terhadap pasien yang menjadi korban malapraktik di dunia kedokteran masih minim. Itu terjadi antara lain karena belum ada peraturan yang mengatur cara menghitung ganti rugi akibat malapraktik. Undang-undang Nomor 29 Tahun 2004 tentang Praktik Kedokteran tidak mencantumkan secara jelas dan rinci tentang perlindungan pasien akibat malapraktik. Dalam UU tersebut tidak ada pengaturan tentang cara menghitung ganti rugi akibat malapraktik, cara mengajukan gugatan malapraktik, standart operating procedure (SOP) rumah sakit, dan sanksi terhadap rumah sakit yang melakukan malapraktik. ${ }^{7}$

Belum adanya Undang-undang yang memberikan perlindungan hak-hak dari pasien dan masih seringnya terjadi malapraktik di Indonesia, mendorong penulis untuk merumuskan masalah dalam tulisan ini, apakah Undang-undang No. 9 tahun 1999 mampu memberikan perlindungan terhadap hak-hak pasien yang juga merupakan konsumen dari pelayanan jasa yang diberikan oleh dokter?

Perlindungan Konsumen menurut Undang-undang No. 8 Tahun 1999 tentang Perlindungan Konsumen

Konsumen, menurut pasal 1 angka 2 UU Perlindungan Konsumen, adalah setiap orang pemakai barang dan/atau jasa yang tersedia dalam masyarakat, baik bagi kepentingan diri sendiri, keluarga, orang lain, maupun makhluk hidup lain dan tidak untuk diperdagangkan. ${ }^{8}$ Kondisi yang demikian pada satu pihak mempunyai manfaat bagi konsumen karena kebutuhan konsumen akan barang dan jasa yang diinginkan dapat terpenuhi serta semakin

7 Baca Hotman Paris Hutapea "Perlindungan terhadap Pasien Korban Malapraktik", dalam Kompas, 9 Desember 2004, hlm. 14.

8 Undang-ndang Republik Indonesia Nomor 8 Tahun 1999 tentang Perlindungan Konsumen, (Jakarta: Setneg RI, 1999), hlm. 3. 
terbuka lebar kebebasan untuk memilih aneka jenis dan kualitas barang dan/atau jasa sesuai dengan keinginan dan kemampuan konsumen. ${ }^{9}$ Di lain pihak, kondisi dan fenomena tersebut diatas dapat mengakibatkan kedudukan pelaku usaha dan konsumen menjadi tidak seimbang dan konsumen berada pada posisi yang lemah. Faktor utama yang menjadi kelemahan konsumen adalah tingkat kesadaran konsumen akan haknya masih rendah. Hal ini terutama disebabkan oleh rendahnya pendidikan konsumen. Oleh karena itu, Undangundang Perlindungan Konsumen dimaksudkan menjadi landasan hukum yang kuat bagi pemerintah dan lembaga perlindungan konsumen swadaya masyarakat untuk melakukan upaya pemberdayaan konsumen melalui pembinaan dan pendidikan konsumen.

Upaya pemberdayaan ini penting karena tidak mudah mengharapkan kesadaran pelaku usaha yang pada dasarnya prinsip ekonomi pelaku usaha adalah mendapat keuntungan yang semaksimal mungkin dengan modal seminimal mungkin. Prinsip ini sangat potensial merugikan kepentingan konsumen, baik secara langsung maupun tidak langsung. Atas dasar kondisi inilah, perlu upaya pemberdayaan konsumen melalui pembentukan Undangundang yang dapat melindungi kepentingan konsumen secara integratif dan komprehensif serta dapat diterapkan secara efektif di masyarakat 10

Perlindungan terhadap konsumen, sebagaimana pasal 1 angka 1 UU Perlindungan Konsumen, adalah segala upaya yang menjamin adanya kepastian hukum untuk memberi perlindungan kepada konsumen. ${ }^{11}$ Tujuannya adalah untuk: (1) Meningkatkan kesadaran, kemampuan dan kemandirian konsumen untuk melindungi diri; (2) mengangkat harkat dan martabat konsumen dengan cara menghindarkannya dari ekses negatif pemakaian barang dan/atau jasa; (3) meningkatkan pemberdayaan konsumen dalam memilih,

${ }^{9}$ Sudaryatmo, Masalah Perlindungan Konsumen di Indonesia, (Bandung: PT Citra Aditya Bakti, 1997), hlm 65.

10 Az. Nasution, Hukum Perlindungan Konsumen (Jakarta: C.V Triarga Utama, 2002), hlm. v

11 Undang-undang Republik Indonesia Nomor 8 Tahun 1999 tentang Perlindungan Konsumen, hlm. 3 
menentukan, dan menuntut hak-haknya sebagai konsumen; (4) menciptakan sistem perlindungan konsumen yang mengandung unsur kepastian hukum dan keterbukaan informasi serta ekses untuk mendapat informasi; (5) menumbuhkan kesadaran pelaku usaha mengenai pentingnya perlindungan konsumen sehingga tumbuh sikap yang jujur dan bertanggungjawab dalam berusaha; dan (6) meningkatkan kualitas barang dan/atau jasa yang menjamin kelangsungan usaha produksi barang dan/atau jasa, kesehatan, kenyamanan, keamanan, dan keselamatan konsumen.

Pihak konsumen maupun pelaku usaha mempunyai hak dan kewajiban yang harus sama-sama dijalankan dan dihormati oleh masing-masing pihak. Dalam Undang-undang No.8 Tahun 1999 dijelaskan Hak-hak konsumen terdapat pada pasal 4 yaitu: (1) Hak atas kenyamanan, keamanan, dan keselamatan dalam mengkonsumsi barang dan/atau jasa; (2) hak untuk memilih barang dan/atau jasa serta mendapatkan barang dan/atau jasa tersebut sesuai dengan nilai tukar dan kondisi serta jaminan yang dijanjikan (3) hak atas informasi yang benar, jelas, dan jujur mengenai kondisi dan jaminan barang dan/atau jasa; (4) hak untuk didengar pendapat dan keluhannya atas barang dan/atau jasa yang digunakan; (5) hak untuk mendapatkan advokasi, perlindungan, dan upaya penyelesaian sengketa perlindungan konsumen secara patut; (6) hak untuk mendapat pembinaan dan pendidikan konsumen; (7) hak untuk diperlakukan atau dilayani secara benar dan jujur serta tidak diskriminatif berdasarkan suku, agama, budaya, daerah, pendidikan, kaya, miskin dan status sosial lainnya; (8) hak untuk mendapat kompensasi, ganti rugi dan/atau penggantian, apabila barang dan/atau jasa tidak sesuai dengan perjanjian atau tidak sebagaimana mestinya; (9) hak-hak yang diatur dalam ketentuan peraturan perundang-undang lainnya. ${ }^{12}$

Selain memiliki hak, konsumen juga memiliki kewajiban yang diatur dalam pasal 5 Undang-undang No. 8 Tahun 1999 Tentang Perlindungan Konsumen, yaitu: (1) Membaca atau mengikuti petunjuk informasi dan prosedur pemakaian atau pemanfaatan barang dan/atau jasa, demi keamanan dan keselamatan; (2) beritikad

12 Ibid., hlm. 6 
baik dalam melakukan transaksi pembelian barang dan/atau jasa; (3) membayar sesuai dengan nilai tukar yang disepakati; (4) mengikuti upaya penyelesaian hukum sengketa perlindungan konsumen secara patut.

\section{Pihak-pihak dalam Perjanjian Pelayanan Medik}

Pelayanan medik adalah untuk memulihkan dan memperbesar kemampuan orang untuk dapat mengatur diri sendiri. ${ }^{13}$ Oleh karena itu, pembatasan yang kadang-kadang harus dilakukan sesuai dengan sifat dari pemberian bantuan tersebut, misalnya, mewajibkan seseorang untuk istirahat, pembiusan yang tidak boleh melebihi kebutuhan, dan sebagainya. Dengan kata lain, kedudukan pemberian bantuan dalam bidang pelayanan kesehatan secara nyata ditentukan oleh hubungan timbal balik antara hak untuk mendapatkan pelayanan dengan hak untuk dapat mengatur diri sendiri.

Apabila tujuan pemberian bantuan secara profesional agar orang dapat mengatur diri sendiri itu tidak dilaksanakan, maka hal tersebut akan menjadi bertentangan dengan sifat dari pemberian bantuannya itu sendiri. Padahal, dapat mengatur diri sendiri adalah sifat dan hak yang fundamental seorang manusia. Seandainya dalam pemberian bantuan pelayanan kesehatan hal itu kurang dipertimbangkan, manusia akan menolak dan membela dirinya.

Pemberian bantuan itu menjadi diperlukan di dalam masyarakat, karena manusia telah menghendakinya, dan manusia itu juga dapat menolak bantuan tersebut, antara lain, dengan alasan memiliki hak untuk mengatur diri sendiri. Dengan demikian, hubungan antara pasien dengan pemberi bantuan profesional (mengatur diri sendiri dengan profesionalitas) lebih tepat untuk dianggap sebagai hubungan kerja sama, dan masing-masing mempunyai kedudukan yang sama. Akan tetapi, tidak dapat dijamin bahwa hubungan kerja sama itu akan mencapai hasil seperti yang diharapkan, sehingga apabila terjadi tidak tercapainya hasil yang diharapkan, maka pemberi bantuan profesional tidak dengan sendirinya dapat dipersalahkan. Setiap orang dapat memperoleh

${ }^{13}$ Leene, Pelayanan Kesehatan, hlm 67 
bantuan secara profesional yang diberikan oleh tenaga kesehatan yang mempunyai keahlian dan kewenangan di bidang kesehatan, dan dalam rangka melakukan tugasnya tenaga kesehatan berkewajiban antara lain menghormati hak pasien. Adapun hak pasien yang dimaksud dalam hal ini adalah hak untuk memberikan persetujuan.

Dari uraian tersebut diatas dapat disimpulkan bahwa tujuan pemberian bantuan pelayanan medis adalah untuk meningkatkan kemampuan menolong diri sendiri dalam menghadapi masalah kesehatannya. Untuk itulah diperlukan adanya persetujuan dari individu yang ditolong, sehingga terciptalah hubungan hukum yang didasarkan kerjasama yang baik, kejujuran serta sikap saling percaya. Dengan demikian, timbulnya hubungan hukum dalam pelayanan medis di samping disebabkan adanya kewajiban setiap individu untuk memelihara dan meningkatkan kesehatannya, juga adanya kewajiban dokter terhadap seseorang yang membutuhkan pertolongannya selaku profesional sampai orang tersebut mampu untuk berusaha mengatasi masalah kesehatannya melalui kerjasama dengan yang merawatnya.

Sebuah perjanjian baik yang nyata maupun diam-diam antara dokter dan pasien seringkali menimbulkan hubungan profesional, sehingga kewajiban yang harus dipenuhi oleh seorang dokter terhadap pasiennya adakalanya dilihat sebagai kewajiban yang didasarkan atas kontrak jasa (service contract). Terdapat hubungan antara dokter dan pasien yang berdasarkan kewajiban pemberian pertolongan medis yang dibebankan oleh masyarakat kepada dokter melalui prinsip perbuatan melawan hukum, dan bukan sebagai peristiwa yang timbul dari kontrak yang ada antara para pihak. Karena itu, kewajiban dokter hendaknnya dilihat sebagai sesuatu yang sebagian besar didasarkan pada hubungan profesional medis, yaitu hubungan yang dapat timbul dalam beberapa konteks dan yang dapat menimbulkan hak serta kewajiban terlepas dari perjanjian yang dibuat oleh para pihak.

Ada dua teori hukum yang menunjang adanya hubungan antara dokter dan pasien, yaitu contract theory dan undertaking theory. Menurut contract theory, jika seseorang dokter setuju untuk merawat seorang dengan imbalan honor tertentu, maka dapat diciptakan 
pengaturan kontraktual yang disertai hak dan tanggung gugatnya. Jika para pihak secara nyata mencapai persetujuan mengenai syarat perawatan, maka dapat timbul kontrak nyata (tegas). Selain kontrak nyata, kontrak secara diam-diam juga dapat terjadi, yaitu disimpulkan oleh pengadilan dari situasinya. Jadi, kontrak baik yang secara nyata maupun diam-diam merupakan sumber yang paling umum dalam hubungan antara dokter dan pasien. Bentuk kontrak seperti ini disebut kontrak tradisional. Apabila dokter merelakan diri untuk memberikan perawatan kepada seseorang, maka tercipta hubungan profesional yang disertai kewajiban perawatan terhadap si penerima. Teori ini memberikan dasar yang memuaskan bagi terciptanya hubungan antara dokter dan pasien dalam kebanyakan situasi yang menyangkut pelayanan medis, termasuk situasi yang tidak diliputi oleh sebuah kontrak.

Selain itu, juga terdapat hubungan insidental, yaitu jika pelayanan dokter dibayar oleh orang yang bukan penerima pelayanan. Namun, karena tujuan utama pelayanan medis adalah memberi perawatan dan pengobatan, hubungan antara dokter dan pasien umumnya ditemukan di bawah teori third party beneficiary atau teori undertaking. Hal ini dianggap tepat, terlepas dari masalah pelayanan itu gratis ataukah dibayar oleh orang lain yang bukan penerima pelayanan. Akan tetapi, adakalanya seorang dokter disewa untuk maksud non therapeutis, misalnya, pemeriksaan kesehatan calon nasabah atau penuntut asuransi, pemeriksaan pelayanan restoran atau karyawan pabrik makanan.

Dari uraian tersebut diatas dapat disimpulkan bahwa dalam hubungan antara dokter dan pasien yang perlu diperhatikan bukan ada atau tidaknya kontrak yang melandasinya, melainkan adanya hubungan profesional dalam pelayanan medik yang dititikberatkan pada pemberian pertolongan yang didasarkan pada kewajiban memberikan perawatan dan pengobatan.

Sementara itu, dalam banyak hal hubungan pemberian pertolongan dalam pelayanan medik adalah didasarkan atas persetujuan antara dokter dengan pasien atau dengan pihak ketiga, sehingga dokter berkewajiban memberikan perawatan dan 
pengobatan. ${ }^{14} \mathrm{Hal}$ ini disebut sebagai perjanjian medis, dan dianggap sebagai perjanjian untuk melakukan beberapa pekerjaan sebagaimana dimaksud dalam Pasal 1601 BW ${ }^{15}$ atau sebagai perjanjian sui generis. Namun demikian, ada kemungkinan pasien mengadakan persetujuan tidak dengan dokter, tetapi dengan rumah sakit sebagai lembaga pelayanan kesehatan, sehingga rumah sakit ikut serta mengurus perawatan dan pengobatan pasien. Dalam hal ini, dapat dibedakan antara perjanjian (contract) di mana rumah sakit hanya berkewajiban untuk melakukan perawatan saja, yaitu disebut sistem all in contract, dan perjanjian di mana rumah sakit di samping berkewajiban melakukan perawatan juga melakukan tindakan lainnya, misalnya pemeriksaan darah yang tidak termasuk perawatan atau pengobatan yang dilakukan oleh dokter sendiri, yaitu disebut sistem all in arts out. Di dalam sistem ini terdapat hubungan kontraktual antara rumah sakit dengan pasien di satu pihak, dan antara rumah sakit dengan dokter di pihak lain. Dalam hal ini, dokter mempunyai kewajiban terhadap rumah sakit untuk mengobati pasien. Bagi para dokter tidak ada kewajiban untuk memberikan bantuan dalam keadaan tertentu yang diatur secara khusus dalam undang-undang, bahkan kewajiban dokter untuk memberikan bantuan dapat timbul dari peraturan tidak tertulis, yaitu jika didasarkan norma kecermatan atau keseksamaan di dalam kasus yang konkret memerlukan bantuan medik.

Kedudukan seorang dokter selaku profesional di bidang medis mempunyai peran aktif dalam pelayanan medis dan pasien sebagai penerima pelayanan medis mempunyai penilaian terhadap penampilan dan mutu pelayanan medis yang diterimanya. Hal ini disebabkan, dokter bukan hanya melaksanakan profesi (ahli) yang terkait pada kode etik profesi. Di samping itu, kenyataan menunjukkan bahwa dengan semakin terdidiknya masyarakat umum dan semakin banyak beredarnya buku pengetahuan populer tentang penyakit dan kesehatan, maka masyarakat awam juga semakin kritis terhadap pelayanan medis yang diterimanya. Kesenjangan

\footnotetext{
14 Istilah perawatan dan pengobatan mengandung maksud sebagai istilah operasional kegiatan pemulihan kesehatan dan penyembuhan penyakit yang berbeda pengertiannya dengan tindakan diagnostis.

15 R. Soebekti dan R. Tjotrosoedibjo, Kitab Undang-Undang Hukum Perdata (Burgerlijk Wetboek) (Jakarta: PT. Pradnya Paramita, 1992), hlm. 62.
} 
pengetahuan, yang secara klasik telah menyebabkan ketidakseimbangan hubungan dokter dan pasien, sekarang semakin mengecil dan mempengaruhi penilaian masyarakat awam terhadap dokter. Lebih dari itu, semakin besar pembagian tugas (division of labour) dalam bidang kedokteran pada berbagai jenis tenaga paramedik dan tenaga non medik, maka makin kurang pula wewenang dokter, dan makin terbuka terhadap penilaian dan kritik. Dengan kata lain, mengecilnnya kesenjangan pengetahuan antara pasien dan dokter, dan semakin terbaginya otonomi profesi dokter kepada pihak lain, akan banyak berpengaruh dalam penilaian dan pengendalian profesi dokter. Dengan demikian, dokter maupun pasien mempunyai hak dan kewajiban yang dilindungi oleh undangundang sehingga kedudukan hukumnya seimbang dan sederajat. Hal ini dapat dilihat dalam ketentuan Undang-Undang Nomor 23 Tahun 1992 pasal 2, yaitu bahwa "setiap orang mempunyai hak yang sama dalam memperoleh derajat kesehatan yang optimal;" dan pasal 53 ayat (1), bahwa "tenaga kesehatan berhak memperoleh perlindungan hukum dalam melaksanakan tugas sesuai dengan profesi."16

Berbagai faktor yang turut mempengaruhi perubahan hubungan antara dokter dan pasien adalah faktor ekonomis, perubahan dalam masyarakat, sikap pribadi pasien terhadap dokter baik terhadap pelayanannya maupun dalam hal berkomunikasi dengan pasien. Di samping itu, para dokter seringkali mempunyai perasaan tertentu yang tidak dapat ditunjukkan dalam hubungannya dengan seorang pasien, misalnya kekecewaan mengenai hasil perawatan yang telah diberikannya, antipati dan simpati, perasaan takut, khawatir untuk mengatakan yang sebenarnya. Kebiasaan untuk menahan perasaan seperti itu mempunyai pengaruh terhadap sikap dokter terhadap pasien. ${ }^{17}$ Selanjutnya, posisi yang lebih kuat daripada dokter juga mempunyai pengaruh terhadap hubungan antara dokter dengan pasien, karena baik disadari maupun tidak terbuka peluang bagi dokter untuk dapat memanipulasi pasiennya, terlebih lagi didukung oleh perasaan takut dari pasien mengenai penyakitnya. Dengan demikian, dokter seringkali mengabaikan

16 Undang-undang No. 23 Tahun 1992 tentang Kesehatan, hlm. 5 dan 12.

17 Sutrisno, Pertanggungjawaban Dokter dan Pembuktian Khususnya dalam Hukum Perdata, (Desertasi, Rijksuniverteit, Leiden, 1989), hlm 21 
kenyataan bahwa pasiennya itu sebenarnya mempunyai pengetahuan yang tidak dimiliki oleh dirinya, misalnya aspek esensial dan aspek kemanusiaan dari penyakitnya itu sendiri. Terlebih pengetahuan yang dimiliki oleh pasien dengan penyakit yang telah menahun (kronik).

Adakalanya sikap pasien juga mempengaruhi hubungan dokter dengan pasiennya. Pasien seringkali kurang mau melihat masalah kemungkinan pemberian bantuan itu menurut pandangan seorang dokter, dan kurang terbuka terhadap dokter yang merawatnya karena kurangnya pengertian. Oleh karena itu, menurut Leenen, hubungan antara dokter dan pasien harus dipandang sebagai hubungan kerja sama yang berada di bawah pengaruh faktor-faktor tersebut diatas, sehingga dapat dikatakan bahwa kedudukan para pihak dalam kerja sama yang demikian adalah tidak sederajat. 18 Meskipun sebenarnya kedudukan dokter dan pasien dalam pemberian pelayanan medis adalah sederajat menurut pandangan hukum perdata. Hukum pada hakikatnya mengatur semua hubungan hukum yang dilakukan oleh setiap subjek hukum, termasuk dokter dalam melaksanakan profesinya yaitu dalam pengobatan (terapeutik) dan dalam penelitian klinis serta penelitian bio medik non klinis.

Pelaksanaan profesi dokter tidak terlepas dari kemajuan ilmu kedokteran yang bertumpu pada penelitian yang pada akhirnya sebagian harus didasarkan atas percobaan pada manusia. Penelitian yang langsung menyangkut diri manusia itu harus bertujuan untuk menyempurnakan tata cara diagnotis (penentuan jenis penyakit yang diderita), terapeutis (cara pengobatan), pencegahan, serta pengetahuan etiologis (asal mula atau penyebab penyakit) dan patogenesisi (perjalanan atau perkembangan penyakit).

Namun, pedoman tersebut merupakan pedoman umum bagi semua dokter di seluruh dunia, sehingga tidak berarti bahwa dokter dibebaskan dari tanggung jawabnya menurut hukum yang berlaku di negara masing-masing. Sebagaimana seharusnya hubungan hukum antara dua subjek hukum, hubungan antara dokter dengan subjek penelitian juga merupakan perikatan. Masing-masing pihak mempunyai hak dan kewajiban secara timbal balik, dan bertanggung

18 Ibid, hlm. 23 
jawab atas pemenuhannya. Akan tetapi, mengingat adanya risiko yang cukup tinggi, dalam prinsip dasar ditentukan bahwa tanggung jawab atas manusia yang diteliti harus selalu terletak pada tenaga medik yang kompeten, meskipun subjek penelitian yang bersangkutan mampunnyai kebebasan kehendak untuk memberikan persetujuannya. Dengan demikian, penelitian hanya dapat dilakukan secara sah apabila kepentingan tujuan penelitian itu sepadan atau seimbang dengan resiko terkait (inhernt) yang akan dihadapi subjek.

Di dalam pelaksanaan sebuah profesi ditemukan argumentasi yang mengatakan bahwa dengan ditetapkannya tanggung jawab yang berat, seorang profesional akan menghormati profesinya. Akan tetapi, harus dijaga jangan sampai para pengemban profesi takut menjalankan profesinya karena tanggung jawab yang berat itu. Sehubungan dengan argumentasi tersebut, para dokter sebagai kelompok profesi yang menjalankan pekerjaan dengan risiko yang cukup tinggi dalam pelayanan medis, akhirnya akan takut mengambil keputusan medis meskipun demi kepentingan pasien. Kenyataan ini menunjukkan bahwa tanggung jawab hukum pada umumnya semata-mata dikaitkan dengan kesalahan dalam menjalankan profesi atau terhadap akibatnya sehingga dokter harus bertanggung gugat.

Namun demikian, yang perlu dipertimbangkan adalah adanya risiko yang tinggi dalam pelayanan medik yang mencerminkan kualifikasi dokter sebagai seorang ahli dalam menangani masalah penyakit pasien. Di samping itu, dokter sebagai aparat pemerintah di bidang kesehatan mempunyai kewajiban yang cukup luas dalam pelayanan kesehatan. Sehubungan dengan adanya risiko yang cukup tinggi yang erat kaitannya dengan tanggung jawab dokter dalam profesinya, besar kemungkinan dilakukan upaya untuk mengalihkan risiko melalui berbagai cara, antara lain dengan persyaratan eksonerasi yaitu pembatasan tanggung jawab. Untuk itulah perlu dipahami terlebih dahulu sifat tanggung jawab hukum dokter dalam pelayanan medis. Dasar pertanggung jawaban hukum dokter dapat berupa pertanggung jawaban karena kesalahan, yaitu merupakan bentuk klasik pertanggungjawaban yang didasarkan atas tiga prinsip, yaitu: Setiap tindakan yang mengakibatkan kerugian atas diri orang lain, meyebabkan orang yang melakukannya harus membayar 
kompensasi sebagai pertanggung jawaban kerugian. Seseorang harus bertanggung jawab tidak hanya karena kerugian yang dilakukannya dengan sengaja tetapi juga karena kelalaian dan/atau kurang hatihati. Seseorang harus memberikan pertanggungjawaban tidak hanya atas kerugian yang dilakukannya sendiri, tetapi juga karena tindakan orang lain yang berada dibawah pengawasannya. Ketiga prinsip tersebut terkandung dalam rumusan pasal-pasal 1365, 1366, 1367 KUHPerdata. ${ }^{19}$

Pertanggungjawaban karena risiko, sebagai kebalikan dari pertanggungjawaban karena kesalahan. Dalam pertanggungjawaban ini, biasanya juga dihubungkan dengan produk tertentu, misalnya obat, peralatan medis atau alat-alat lainnya. Di dalam memenuhi kebutuhan dan perkembangan yang terjadi dalam hubungan hukum, fungsi hukum dalam melindungi kepentingan manusia akan berorientasi pada tanggung jawab atau kewajiban dan risiko. Akan tetapi, karena berkembangnya hubungan hukum yang terjadi di dalam masyarakat dipengaruhi oleh berbagai faktor, terjadi di dalam masyarakat dipengaruhi oleh berbagai faktor, terjadi ketimpangan atau ketidakseimbangan antara tanggung jawab atau kewajiban dan risiko. Oleh karena itu, berdasarkan asas kebebasan kehendak yang berlaku dimungkinkan dilakukannya syarat untuk membatasi, mengurangi atau membebaskan tanggung jawab atau kewajiban tertentu dari salah satu pihak, atau membagi beban risiko yang layak.

Ada beberapa hal yang perlu diperhatikan untuk menguji diperlukannya exoneratieclause dalam suatu hubungan hukum, yaitu, (1) beratnya kesalahan, (2) sifat dan isi perjanjian, (3) kedudukan dalam masyarakat serta hubungan antara para pihak satu sama lain, (4) cara terjadinya syarat eksonerasi, dan (5) besarnya kesadaran pihak lain akan maksud dan syarat yang bersangkutan.

Berdasarkan uraian diatas dapat disimpulkan bahwa syarat eksonerasi dalam pelayanan medis hanya dimungkinkan pada pertanggungjawaban karena risiko, dan pada asasnya hanya berlaku bagi para pihak, sama halnya dengan tujuan utama pertanggungan (asuransi), yaitu mengalihkan risiko yang ditimbulkan dari peristiwa yang tidak dapat diharapkan terjadinya. Pertanggungan yang dapat

19 Ibid., hlm 89 
digunanakan dalam profesi dokter tersebut merupakan professional liability insurance yang juga dikenal dengan nama malpractice liability insurance ini ditutup atas risiko financial responsibility orang-orang yang di dalam profesinya menimbulkan kerugian pada orang lain. ${ }^{20}$

\section{Penutup}

Dalam pasal 71 UU No. 23 Tahun 1992 ditegaskan bahwa penyelenggaraan kesehatan merupakan tanggung jawab bersama pemerintah dan masyarakat. Dengan demikian, masyarakat tidaklah menjadi objek semata, tetapi sekaligus merupakan subjek penyelenggaraan upaya kesehatan. Kedudukan hukum para pihak dalam pelayanan medis adalah seimbang sesuai dengan tanggung jawabnya masing-masing. Pasien bertanggung jawab atas kesehatannya dan atas segala upaya kesehatan yang dilakukan terhadap dirinya, dan dokter bertanggung jawab karena profesinya di bidang medis yang memiliki ciri pelayanan berupaya pemberian bantuan atau pertolongan yang seharusnya selalu berupaya meningkatkan keahlian dan ketrampilannya melalui penelitian (profesional).

Dalam melaksanakan perjanjian antara dokter dan pasien bukan merupakan perikatan hasil (result verbintebis) namun adalah perikatan ikhtiar (inspanning ikhtiar) sebagai suatu upaya atau usaha terukur. Undang-undang Perlindungan Konsumen bisa menjadi payung dalam kaitannya hubungan pelayanan medik, sebab bisa dikategorikan menjadi pelayanan jasa sebagaimana disebutkan dalam pasal 1 ayat (5) UU No. 8 tahun 1999, selain ketentuan yang diatur dalam Kitab Undang-Undang Hukum Perdata dan Undang-Undang Praktik Kedokteran. Beberapa Pasal dalam Undang-Undang No 8 Tahun 1999 juga dapat dijadikan acuan, khususnya yang mengatur masalah hak dan kewajiban para pihak, yakni pasien, yang kedudukannya seperti konsumen jasa, dan dokter, yang kedudukannya seperti produsen dalam hal pelayanan jasa. Wallâh a'lam bi al-shawab.

20 Ibid, hlm. 103 
Elvie Wahyuni

\section{Daftar Pustaka}

Hutapea, Hotman Paris. "Perlindungan terhadap Pasien Korban Malapraktik", Kompas, 9 Desember 2004

Leene, H.J.J Lamintang, P.A.F. Pelayanan Kesehatan dan Hukum. Jakarta: Bina Cipta, 1991

Nasution, Az. Hukum Perlindungan Konsumen. Jakarta: C.V Triarga Utama,2002

Redaksi, Perlindungan hukum terhadap Pasien sebagai Pengguna Jasa Pelayanan Kesehatan: $\quad$ http://www.skripsihukum.com / tesis/98543. html (diakses tanggal 2 Nopember 2007).

Soebekti, R. dan Tjotrosoedibjo, R. Kitab Undang-Undang Hukum Perdata (Burgerlijk Wetboek). Jakarta: PT. Pradnya Paramita, 1992

Sudaryatmo, Masalah Perlindungan Konsumen di Indonesia. Bandung: PT Citra Aditya Bakti, 1997

Sutrisno, Pertanggungjawaban Dokter dan Pembuktian Khususnya dalam Hukum Perdata (Desertasi, Rijksuniverteit, Leiden, 1989)

Undang-undang Republik Indonesia Nomor 8 Tahun 1999 tentang Perlindungan Konsumen. Jakarta: Setneg RI, 1999

Undang-undang Republik Indonesia Undang-undang Nomor 23 Tahun 1992 tentang Kesehatan. Jakarta: Setneg RI, 1999 